\title{
Os valores-notícia pelas lentes dos ombudsmen nos jornais brasileiros
}

\author{
Marcelo Engel BRONOSKY ${ }^{1}$ \\ Daniela BORCEZI ${ }^{2}$
}

\begin{abstract}
Resumo:
O presente trabalho busca identificar e/ou atualizar alguns parâmetros de crítica jornalística praticada pelos ombudsmen na imprensa brasileira. A ideia é enfocar, num intervalo de dez anos, a trajetória dos ombudsmen e possíveis mudanças na crítica jornalística realizada em suas colunas. $\mathrm{O}$ desenvolvimento desta pesquisa procura recuperar estudos realizados há uma década por um dos autores (BORCEZI, 2008), que discutia, de forma transversal, os valores-notícia presentes na crítica dos ombudsmen nos jornais impressos Folha de S. Paulo (São Paulo), O Povo (Fortaleza, Ceará) e Jornal da Manhã (Ponta Grossa, Paraná). Neste artigo, propõe-se olhar para essas manifestações, a fim de reconhecer, por meio das críticas, eventuais mudanças no próprio produto jornalístico. Desse modo, admite-se as seguintes proposições: Quais são os valores-notícia observados pelas lentes dos ombudsmen? Que parâmetros são mobilizados? Essas são algumas preocupações que atravessam este artigo.
\end{abstract}

Palavras-chave: Ombudsman brasileiro. Crítica jornalística. Valores-notícia. Midiatização.

\section{The news values of the lenses of ombudsmen in Brazilian newspapers}

\begin{abstract}
:
This research seeks to identify and/or update some parameters of journalistic criticism practiced by the ombudsmen in the Brazilian press. The idea is to focus, within 10 years, the trajectory of the ombudsmen; possible changes in the journalistic critique made through these columns of text. The development of this research seeks to recover studies carried out a decade ago by one of the authors (BORCEZI; 2008), who discussed, in a transversal way, the news values present in the critique of ombudsmen in printed newspapers: Folha de S. Paulo, O Povo (Ceará) and Jornal da Manhã (Ponta Grossa). On this paper, it is proposed to look at these manifestations, in order to recognize through the possible criticisms changes in the journalistic product itself. In this way, aknowledge from the following propositions: What are the news values observed by the lenses of the ombudsmen? What parameters are mobilized? These are some concernes that go through this article.
\end{abstract}

Keywords: Brazilian ombudsman. Journalistic criticism. News values. Mediatization.

\section{Los valores de las noticias a través de la lente de los defensores del pueblo en los periódicos}

\section{Resumen:}

El presente trabajo busca identificar y/o actualizar algunos parámetros de crítica periodística practicados por los defensores del pueblo en la prensa brasileña. La idea es enfocar, en un intervalo de diez años, la

\footnotetext{
' Doutor em Ciências da Comunicação, professor dos cursos de Graduação e Mestrado em Jornalismo da Universidade Estadual de Ponta Grossa - Pr. E-mail: mebrono@gmail.com

2 Mestre em Jornalismo pela Universidade Estadual de Ponta Grossa - Pr. E-mail: danielaborcezi@gmail.com.
} 
trayectoria de los defensores del pueblo y los posibles cambios en la crítica periodística realizada en sus columnas. El desarrollo de esta investigación busca recuperar estudios realizados hace una década por uno de los autores (BORCEZI, 2008), quien discutió, de manera transversal, los valores de las noticias presentes en la crítica de los defensores del pueblo en los periódicos impresos Folha de S. Paulo (São Paulo), O Povo (Fortaleza, Ceará) y Jornal da Manhã (Ponta Grossa, Paraná). En este artículo, se propone observar estas manifestaciones para reconocer, a través de la crítica, posibles cambios en el producto periodístico en sí mismo. Por lo tanto, se admiten las siguientes proposiciones: ¿Cuáles son los valores de noticias observados a través de los lentes de los defensores del pueblo? ¿Qué parámetros se movilizan? Estas son algunas preocupaciones que pasan por este artículo.

Palabras clave: Defensor del pueblo brasileño. Crítica periodística. Noticias de valores. Mediatización.

\section{Introdução}

O desenvolvimento desta pesquisa originou-se da releitura do trabalho de conclusão de curso no curso de Jornalismo da Universidade Estadual de Ponta Grossa, intitulada Os vigilantes também são vigiados: o papel do ombudsman nos jornais brasileiros, em que se discutem os valores-notícia presentes na crítica dos ombudsmen em jornais impressos brasileiros, no ano de 2008. Embora as colunas fossem iniciativa de apenas três diários, em âmbito nacional (Folha de S. Paulo), estadual (O Povo) e regional (Jornal da Manhã), as críticas dos ombudsmen apresentavam peculiaridades e similitudes, além das características inerentes a sua função, como comparar a produção jornalística com demais veículos de comunicação, dar sentido pedagógico às informações e até mesmo se autorreferenciar como representante do leitor. No entanto, a distinção dos ombudsmen revelou-se nos seus parâmetros de criticidade, que tinha como norteadores o Manual de redação (Folha de S. Paulo), a manifestação dos leitores ( $O$ Povo) e a rotina de produção de um jornal (Jornal da Manhã) (BORCEZI, 2008).

Por tratar-se de uma crítica jornalística que concentra pluralidade de vozes sobre o mesmo produto, inclusive de leitores e jornalistas na coluna do ombudsman, notou-se que as manifestações da época não se pautavam apenas nos temas das notícias, mas na produção jornalística, o que caracteriza um elemento selecionador de divulgação das cartas dos leitores. Já a participação dos jornalistas não era constante nas colunas dos ombudsmen e suas manifestações estavam voltadas para certa autodefesa.

Neste cenário, as notícias políticas foram os temas que mais receberam críticas, principalmente os assuntos que envolveram intrigas e escândalos políticos. Aqui, os valores-notícia mencionados pelos ombudsmen foram o interesse público e critérios de noticiabilidade como atualidade e proximidade, além de um posicionamento plural e imparcial do jornal.

Mas, qual a importância desta pesquisa para o contexto atual do jornalismo? De 
dez anos para cá, a intensificação do uso de dispositivos digitais provocou mudanças substanciais nos modos de se produzir notícias. Os mecanismos de produção foram impactados não apenas pelo crescimento exponencial das plataformas digitais, mas também as decisões passaram a considerar outros aspectos quando da definição de notícia. Isso nos instiga a recuperar e atualizar os parâmetros da crítica jornalística pelas lentes do ombudsman e reconhecer as mudanças do próprio produto jornalístico. Portanto, para responder às proposições deste trabalho e evidenciar os parâmetros mobilizados pelos ombudsmen, a pesquisa concentrou-se nos jornais brasileiros que conservaram o espaço de crítica desde 2008, Folha de S. Paulo e O Povo.

Num primeiro momento, recupera-se neste artigo breve história dos tradicionais jornais brasileiros com espaço para ombudsman e as iniciativas regionais dessas críticas no jornalismo paranaense, como do Jornal da Manhã, que perdurou de 2007 até 2011. Em seguida, discutem-se os atuais parâmetros da crítica jornalística e os valores-notícia referenciados pelos ombudsmen.

\section{O ombudsman e as plataformas digitais}

Jairo Mendes (2002), entre outros autores, explica a origem da palavra, por vezes, estranha aos leitores brasileiros. O ombuds (representante) man (cidadão) é uma palavra escandinava que surgiu na administração pública em 1809 e passou a ser utilizada pelos jornais a partir do século XX com variadas denominações: "provedor do leitor” (Portugal), “mediador” (França), "representante do leitor” (Espanha e Japão) ou então “ouvidor” (Brasil, Suécia, Estados Unidos e Canadá) (MENDES, 2002; BORCEZI, 2008; BRONOSKY, 2010).

No Brasil, Caio Túlio Costa foi o primeiro jornalista assumir a função de ombudsman na Folha de S. Paulo, em junho de 1989. Desde então, o espaço tornou-se tradição na imprensa brasileira, sendo interrompido num curto intervalo de tempo em 2008, com o desligamento do jornalista Mário Magalhães, o qual não concordava com a política editorial de restrição das críticas do ombudsman no portal da Folha (BRONOSKY, 2010). Segundo Fausto Neto (2008, p. 7), o episódio representa “complexas transformações provocadas pela emergência de novos processos sociotécnicos e seus impactos sobre os processos interacionais, envolvendo o campo midiático e os atores individuais, enquanto seus receptores".

Cabe destacar que o pioneirismo da Folha de S. Paulo inspirou o cargo de 
ombudsman em demais jornais brasileiros, como no Correio da Paraíba, em maio de 1991, e no jornal O Povo do Ceará, em 1993, com a jornalista Adísia Sá, primeira mulher assumir a função de ombudsman no país. Historicamente, o Correio da Paraíba é o precursor da crítica jornalística na região Nordeste, "surgindo dois anos antes da criação no impresso cearense $O$ Povo, que, quiçá por desconhecimento, quiçá por estratégia de marketing, clama para si o pioneirismo regional" (ROSAS; PRUDENCIO, 2014, p. 12).

Já as colunas dos ombudsmen nos jornais do estado do Paraná não se consolidaram ao longo dos anos. Tem-se conhecimento do pioneirismo do Jornal da Manhã na cidade de Ponta Grossa com o professor e jornalista Sérgio Luiz Gadini, em setembro de 2007, e a iniciativa de O Estado do Paraná, que funcionou no formato digital por breves três meses, de março a abril de 2008 (GADINI, 2017). No caso do Jornal da Manhã, a ideia originou-se com a reformulação gráfica e editorial do periódico, focado no jornalismo público. Na época, a proposta ocasionou espanto para os profissionais da mídia e leitores do referido periódico, que não estavam acostumados com a autocrítica do jornal (BORCEZI, 2008).

A tradição local, contudo, não era marcada por interações com leitores e interlocutores dos produtos jornalísticos. Tanto que, só em 1999, quando o Diário dos Campos - concorrente direto do JM - voltou a circular, que os impressos passam a abrir espaço cotidiano para leitores, seja como artigo, comentário ou mesmo eventuais críticas. E, claro, tal ampliação estava já em sintonia com a ampliação das interações digitais com a proliferação do acesso à internet (GADINI, 2017, p. 192).

Contudo, no primeiro mandato do ombudsman foi notável a expressiva participação dos leitores, pois, já na terceira edição, o espaço de meia página já ganhava uma página inteira, o que "coloca sob suspeita" a perspectiva de que os "leitores da cidade não tinham o hábito de escrever" para o jornal (GADINI, 2017, p. 193).

No decorrer de três anos e meio, o cargo de ombudsman do Jornal da Manhã também foi assumido pelas jornalistas Elaine Javorski (2008-2009), Alessandra Perrinchelli (2009-2010) e Vanessa Zappia (2010-2011). Segundo Gadini (2017, p. 194), a direção do jornal não apresentou justificativa para o encerramento da coluna do ombudsman, mesmo com diversas manifestações registradas contra a decisão do grupo.

Uma questão que atravessa a história dos 10 anos de ombudsman no país é se a imprensa tradicional mantém o representante do leitor ou os espaços de crítica estão sendo reinventados com as novas plataformas digitais. Na tentativa de buscar respostas 
e indícios de transformações desse fenômeno, verificou-se historicamente que, com a expansão da internet, os ombudsmen migraram do impresso para o digital, na perspectiva de reproduzir o mesmo conteúdo. Segundo Madeira e Cardoso (2016, p. 8), essa migração não aconteceu de modo regular com as colunas dos ombudsmen, pois a Folha de S. Paulo e O Povo "não modificaram seu modo de atuação propriamente dito ao publicarem na rede - como foi possível constatar a partir de uma análise dos conteúdos disponíveis em seus respectivos websites".

Embora os jornais tenham adaptado o espaço do ombudsman nos meios digitais desde o boom da internet nos anos $2000,{ }^{3}$ assume-se que a atuação desses profissionais foi impactada pela midiatização, inclusive com a recente incorporação das redes sociais na análise do produto jornalístico e na comunicação com os leitores.

É sintomática a escassez da figura do ombudsman nos tradicionais jornais brasileiros, no intervalo de dez anos desta pesquisa. No período, mantiveram-se dois representantes do leitor na Folha de S. Paulo e no jornal O Povo. Essa mesma tendência foi verificada no jornalismo autodenominado independente, segundo pesquisa desenvolvida por Bronosky e Santos (2016). Dos 80 canais mapeados pela Agência Pública em 2016, em apenas dois se constataram iniciativas de ombudsmen: Livre Jor e Revista Berro. Atualmente não há dados novos sobre esses resultados, permanecendo a mesma quantidade de ombudsmen. As mídias independentes não avançaram nessa proposta, visto que as colunas dos ombudsmen desses websites não são alimentadas periodicamente e somente há texto de abertura para as críticas de mídia. No entanto, verificou-se iniciativa esporádica ${ }^{4}$ como da Agência Lupa, que implantou durante a campanha eleitoral de 2018 o ombudsman. A coluna foi comandada pela jornalista e professora Fernanda da Escóssia.

Em relação à ausência do representante do leitor nos jornais, cogitam-se algumas hipóteses neste cenário de midiatização: a substituição do ombudsman por novos canais de interação com o leitor, expansão das agências de fact-checking no controle da qualidade da informação. Estas apostas são pertinentes para analisar a sobrevivência dos ombudsmen nos jornais na atual conjuntura midiática. A princípio, neste artigo o objetivo é verificar as eventuais mudanças de atuação do ombudsman com os novos fluxos de informação e os valores-notícia mobilizados pelo crítico de mídia.

\footnotetext{
3 Os sites $i G$ e $U o l$ adotaram a coluna do ombudsman em 2007, porém as experiências duraram menos de um ano (FRANZONI, 2009).

${ }_{4}^{4}$ Os 11 textos foram publicados do dia 28/08/2018 a 01/11/2018.
} 
Análise

O percurso metodológico deste trabalho caracteriza-se por uma análise de conteúdo das colunas dos ombudsmen na versão on-line dos jornais Folha de S. Paulo e O Povo, nos meses de abril e maio de 2018, período em que a mídia não estava préagendada por mega acontecimentos da Copa do Mundo e eleições presidenciais. A pesquisa encontrou 17 textos: nove da Folha e oito de O Povo. As colunas foram analisadas por temas, valores-notícia e tipos de leitores, conforme categorias de análise estabelecidas no trabalho de conclusão de curso desenvolvido no curso de Jornalismo da Universidade Estadual de Ponta Grossa, em 2008. Nessa última categoria foi aplicada a classificação dos tipos de leitores, que se manifestam na coluna do ombudsman na perspectiva do jornalista português Mesquita (2002): leitor tipo - manifesta-se em causa própria, pois foi objeto de tratamento de uma informação, que considera inexato ou incorreto; leitor cidadão - discute a qualidade informativa do jornal; leitor especialista - profissionais da imprensa que se manifestam na coluna do ombudsman e o leitor fonte - que intervém na elaboração da informação.

Ao revisitar conceitos e atualizá-los nesta pesquisa, a metodologia pré-concebida foi ajustada e adequada conforme os novos fenômenos identificados no corpus de análise em: interdiscursividade, produção da notícia, autorreferencialidade, tematização, manuais de redação, manifestação dos leitores e dos profissionais da redação.

\section{O ombudsman da Folha de S. Paulo: o interdiscurso}

As principais mudanças de posição do ombudsman podem ser observadas na sua enunciação com os leitores e nos novos parâmetros de criticidade dos processos jornalísticos incitados pela midiatização. Nesse contexto, a incorporação de novos fluxos de informação do jornal com o público resultou em novas mediações na produção da notícia (CARVALHO; LAGE, 2012).

Para Fausto Neto (2008), a função do ombudsman foi impactada por esse dinamismo e provocou novas tensões e ressignificações de conteúdos por parte de outros atores sociais. "A reflexão sobre os processos jornalísticos continua sendo a sua matéria-prima. Emerge nova dinâmica interacional que coloca o ombudsman numa outra relação com o leitor" (FAUSTO NETO, 2008, p. 12). 
Na Folha de S. Paulo, o enunciado da ombudsman Paula Cesarino Costa ${ }^{5}$ segue regido por tal perspectiva, inclusive pelas intervenções do público nas redes sociais do jornal. A coluna da ombudsman intitulada "Distanciamento histórico", do dia quatro de abril de 2018, registra a falta de credibilidade do jornal referente à publicação de uma reportagem no Twitter, intitulada "Há 50 anos". A postagem é uma foto das manifestações de 1968 com a chamada "Protestos levam cúpula militar a avaliar adoção de estado de sítio". O texto provocou reações nos leitores, que interpretaram a informação como se fosse atual, pois o contexto político brasileiro estava acalentado com as discussões sobre a intervenção militar no Rio de Janeiro e por conta dos protestos da prisão do ex-presidente Luís Inácio Lula da Silva.

Para reforçar ainda mais o sentido dessa publicação, o general Eduardo Villas Bôas fez declarações polêmicas no mesmo dia em suas redes sociais, indagando sobre quem pensa no bem do Brasil e assegurou apoio aos brasileiros com a seguinte mensagem: "O Exército Brasileiro julga compartilhar o anseio de todos os cidadãos de bem de repúdio à impunidade e de respeito à Constituição" (COSTA, 2018). O assunto teve repercussão na mídia nacional, pois muitos interpretaram a manifestação como uma pressão do general ao Supremo Tribunal Federal sobre o julgamento de Lula. O episódio foi uma das interlocuções da ombudsman com o público, o que sinaliza a participação complexa dos dispositivos da internet na agenda da produção noticiosa, pois, nesse caso, os fatos exteriores à redação da Folha colaboraram para legitimar uma informação descontextualizada.

\footnotetext{
Qualquer coisa hoje, nas redes sociais, é dada como verdade, sem mesmo as pessoas terem lido. Notícias que se encaixam no contexto em que vivemos viralizam e têm maior poder de convencimento. Divulgar matéria de 50 anos atrás, sem indicar explicitamente do que se trata, é uma imprudência enorme. A Folha espalhou fake news e desinformação (COSTA, 2018, não paginado, grifo da autora).
}

A interdiscursividade articulada na coluna do ombudsman e a pressão dos leitores gera um sistema de resposta, intencional ou não, para o próprio jornal em relação ao deslize jornalístico. Aqui, entende-se que essa dimensão enunciativa provoca inquietações e posicionamentos defensivos dos profissionais. Na concepção de Fausto Neto, a interdiscursividade está submetida aos efeitos da linguagem, que também são causadores de surpresas e aborrecimentos. Assim, os atores sociais podem se encontrar

\footnotetext{
${ }^{5}$ Exerceu a função de ombudsman entre maio de 2016 a abril de 2019, sendo substituída por Flávia Lima.
} 
"constrangidos" ou "mobilizados" a enunciar-se para além das suas intenções (FAUTO NETO, 2010, p. 8).

Na coluna de Paula Cesariano Costa há uma constante presença de profissionais da Folha se retratando sobre os problemas de informação, como o editor de mídias sociais Ygor Salles, que reconheceu a falta de clareza da publicação de 1968, pois se tratava de um evento histórico. Nisso, explicou que o "efeito é ainda maior no Twitter, onde inexistem os elementos gráficos que permitam sinalizar a diferença" (COSTA, 2018, não paginado). Ao assumir o erro, a Folha decidiu modificar o procedimento de publicação na rede social e então as notícias do banco de dados e do acervo da Folha passaram a ser identificadas pelo ano já no título da postagem.

Ao observar as críticas do ombudsman, Braga (2006) observa que existe "sensibilidade" de relacionamento entre a crítica e o produto avaliado, pois há consenso dos pares sobre os valores que podem ser referenciados à prática jornalística, bem como a reflexão de novos padrões jornalísticos a serem estabelecidos. Neste sentido, a coluna do ombudsman se caracteriza por um processo mais negociado que polemizado. "A simples possibilidade dessa negociação de interpretação gera uma crítica compreensiva e matizada, que funciona mais na sutileza que no embate frontal" (BRAGA, 2006, p. 102).

Em relação à visibilidade dos profissionais da Folha na coluna da ombudsman entre os anos de 2008 e 2018, pode-se dizer que houve aumento dessas manifestações, conforme mostra o Gráfico 2. Isto pode significar o estreitamento dessa negociação com os jornalistas diante dos avanços da midiatização. Com isso, reformulam-se os "contratos de leitura", possibilitando mudanças de relações entre " "processos produtivos' e os de recepção de mídias, estreitando rotinas e percepções de seus mundos, tornando doméstico o que até então parecia, apenas, realidade intrínseca à cotidianidade dos produtores de informação" (FAUSTO NETO, 2008, p. 7). Ou seja, ampliou-se o reconhecimento dos processos de produção pelo conjunto dos consumidores, bem como a necessidade de evidenciá-los na manufatura das notícias.

\section{Além da pauta}

Carvalho e Lage (2012) observam a necessidade de interação dos jornais com os novos fluxos de informação das redes sociais, as quais articulam acontecimentos e operam como fontes crescentes nos processos jornalísticos. Ao mesmo tempo que a 
participação dos leitores como denunciantes e opinantes dos fatos não é uma novidade, de outro modo eles não estão mais à margem do processo da notícia, pois o fazer jornalístico também é compartilhado com o público.

A presença de novas intervenções na produção da notícia foi um dos assuntos pautados pela ombudsman da Folha no comentário "Esperando João na rua errada", do dia seis de maio de 2018. A crítica jornalística refere-se à publicação da crônicareportagem sobre o artista brasileiro João Gilberto, que foi descrita a partir de uma fracassada entrevista com moradores do Leblon, no Rio de Janeiro, sobre o paradeiro do cantor. Até então, o texto divulgado nas redes sociais ganhou elogios, quando um jornalista experiente postou que o cantor morava em outro endereço e a Folha teve que corrigir o erro de informação. "Houve um espirituoso que resumiu a encrenca, citando texto de Samuel Beckett sobre um personagem que nunca chega: 'A Folha esperou Godot na rua errada" (COSTA, 2018). No entanto, o problema demorou 21 dias para ser corrigido, de modo não objetivo, como preconizado pelo Manual da redação.

Nessa crítica da ombudsman, dois aspectos são relevantes: o primeiro diz respeito ao furo de reportagem advindo de um leitor especialista nas redes sociais e o constrangimento por parte do jornal em assumir a falta de apuração jornalística. Aqui, o sistema produtivo passa a ser regido por lógicas mais complexas, o que sugere "o reordenamento do processo jornalístico de construção da realidade, mas, por consequência, também colocam em questão a própria noção de acontecimento" (CARVALHO; LAGE, 2012, p. 259).

Já o segundo aspecto dessa abordagem refere-se aos parâmetros de crítica da ombudsman. Embora haja a colaboração de novos participantes na construção da notícia, a produção jornalística está submetida às normas organizacionais, como revelado pelo descumprimento das normas do Manual da redação. O uso desse dispositivo pela ombudsman não é recorrente, pois se trata do único caso em que o Manual de redação foi referenciado de modo direto, no decorrer de dois meses. Se comparar a apropriação do manual pelos ombudsmen, no mesmo período em 2008, a coluna semanal do ex-ombudsman da Folha Carlos Eduardo Lins da Silva tinha como principal critério avaliativo das notícias, o Manual de redação.

Já os estudos de Bronosky (2010), que abrangem as críticas jornalísticas da Folha entre 1994 e 2008, apontam intensa utilização do Manual de redação na gestão do então ombudsman Mário Magalhães. Um dos aspectos problematizados pelo autor 
diz respeito ao modo com que as normas são referenciadas no texto, pois o ombudsman tende a relativizá-las nos processos jornalísticos, no sentido de revelar que o modo de produção transcende as determinações do manual, bem como reitera a importância de segui-las.

\begin{abstract}
Assim, o debate público provocado pelo ombudsman tende a revelar discrepâncias, tensões, desvios cometidos pelos jornalistas e pelo jornal, questionando em muitos aspectos as regras do próprio manual e/ou seu cumprimento. Ao fazê-lo, o ombudsman tem a oportunidade de provocar debate junto a redação, já que segundo manda a tradição da Coluna, sempre é dado ao jornalista o direito de responder, explicar por vezes, seus procedimentos (BRONOSKY, 2010, p. 119).
\end{abstract}

No entanto, essa dinâmica de reavaliar procedimentos com referência ao Manual de redação não foi constatada na atual coluna da ombudsman da Folha, o que se mostra no mínimo curioso, pois o Manual chegou a sua $5^{\text {a }}$ edição no ano de 2018 já com a inclusão de temas sobre a postura profissional nas redes sociais e fake news. Neste aspecto, o espaço do ombudsman poderia servir para informar mudanças adotadas pelo jornal, como sugerido pelo autor.

\title{
Um convite
}

O discurso autorreferencial das mídias jornalísticas é uma das características sintomáticas de uma sociedade em vias de midiatização. Esse modelo de enunciação visa assegurar ao jornalismo seu lugar de fala, como mediador legítimo de informações e acontecimentos. Na perspectiva de Carvalho e Lage (2012), a participação do público nas operações jornalísticas não representa apenas disputa por visibilidade, mas trata-se do consentimento dos meios de comunicação nesse modo de produção.

\footnotetext{
Como parte de uma estratégia de aproximação, leitores, ouvintes e espectadores são cada vez mais chamados a colaborar, a participar do processo de produção das notícias. Assim, são postos na condição de coprodutores. Investidos no papel do "eu repórter", esses agentes não apenas denunciam, como também produzem e reproduzem o próprio material jornalístico (fotos, vídeos, notícias...), direta ou indiretamente, corrigem e atualizam informações, reafirmando e ressaltando sua importância nos processos de mediação implicados nas operações jornalísticas - modificando, assim, a própria prática jornalística enquanto mediação social (CARVALHO; LAGE, 2012, p. 263).
}

Esse novo protocolo de interação reposicionou o discurso do ombudsman, porém deve-se reconhecer que o mesmo está submetido a um regime enunciativo de duas ordens, o mercadológico e a serviço do público (FAUSTO, 2010). Em uma "sociedade 
dos meios" (FAUSTO NETO, 2010, p. 5), quando as mensagens estavam restritas à carta e e-mail, o ombudsman anunciava-se como um ouvidor que recebia, investigava e encaminhava as reclamações do público para a redação. Percebe-se que a coluna da ombudsman da Folha buscou recuperar esse sentido ao solicitar a participação dos leitores via ombudsman, na perspectiva de se autorreferenciar mediador das críticas jornalísticas.

Tal análise pode ser observada no texto "Por um fio", do dia 22 de abril de 2018, quando são feitas críticas sobre o projeto gráfico do jornal impresso e a ombudsman convida os leitores a experimentar a nova versão e enviar uma opinião. $\mathrm{O}$ assunto retornou na semana seguinte com a seguinte descrição: "Leitores atenderam com entusiasmo o convite para comentarem o novo projeto gráfico. Se, nos primeiros dias, a totalidade das mensagens que recebi reclamava da reforma, durante a semana, 2 em cada 10 leitores fizeram elogios à Folha. Menos mal" (COSTA, 2018, não paginado).

Nessa enunciação a ombudsman tenta estabelecer uma mediação com os leitores por meio de um espaço institucionalizado, um modo de operação que foi afetado pelas novas interações. "Uma plataforma circulatória assegura por suas condições que menores restrições tratem de distinguir as posições e lugares de produtores e de receptores" (FAUSTO NETO, 2010, p. 6). Para ele, muda-se o protocolo de ações interpretativas do ombudsman e das suas condições de fala, pois estão atravessados por dispositivos que operam em colocar os leitores em contato entre si e de modo instantâneo.

\section{Ombudsman do jornal O Povo}

Em uma "sociedade em vias de midiatização" (FAUSTO NETO, 2010, p. 6), é peculiar observar as críticas jornalísticas de $O$ Povo, pois o texto não evidencia uma nova posição discursiva do ombudsman, mesmo com a dinamização dos recentes fluxos de informação. Desde fevereiro de 2018, a coluna é escrita pela jornalista Daniela Nogueira e o texto é disponibilizado na íntegra no portal do jornal. Para chegar à conclusão acima, dois aspectos foram observados: as críticas estão direcionadas para o jornal impresso, com poucas ressalvas ao digital, e o discurso da ombudsman não está necessariamente atravessado pelos novos dispositivos de interação, como os comentários das redes sociais do jornal, por exemplo.

Neste sentido, o espaço do ombudsman mantém suas características de origem 
como mediador, ao gerenciar o funcionamento do contrato de leitura entre o produtor e receptor, de modo que "pudessem ser afastadas as possibilidades de 'fugas' e 'desvios' dos receptores do mundo producional" (FAUSTO NETO, 2008, p. 5). Tal perspectiva pode ser notada no texto "Equilíbrio, notícia e espetáculo" do dia oito de abril de 2018, em que a ombudsman explicita seu vínculo com o leitor.

Com a reforma gráfico-editorial do O POVO, informações de serviço sobre os filmes em exibição, com horários, salas e locais, haviam sido retiradas do impresso. Desde a segunda quinzena de janeiro, os leitores não tinham mais acesso a esses dados pelo jornal de papel. A programação passaria a ser publicada no portal e no aplicativo Agenda Vida\&Arte.

As queixas, inclusive mencionadas neste espaço, foram muitas. Leitores, insatisfeitos com a supressão do serviço, alegavam que, sim, consumiam a informação pelo impresso, que O POVO reavaliasse sua decisão para atender a um público que exigia o serviço de volta (NOGUEIRA, 2018, não paginado, grifo nosso).

Diferente do ombudsman da Folha, os parâmetros de crítica do jornalismo nordestino não estão submetidos à lógica dos novos processos interacionais, ao menos não é um critério referenciado na análise do produto. Percebe-se que a crítica da ombudsman manteve duas características: a primeira refere-se à ausência de citação do Manual de redação. Cabe ressaltar que o jornal possui na sua política editorial o Guia de redação e estilo O Povo e, desde 2016, o Manual de uso das mídias digitais. Já a segunda diz respeito à divulgação nominal dos jornalistas com o produto criticado, algo que pareceria ousado na época. Hoje, acredita-se que a transparência se faz cada vez mais presente nas críticas dos ombudsmen, pois até a Folha adotou esse procedimento.

De outro modo, as questões éticas implicadas na produção jornalística se sobressaíram na avaliação das notícias nas colunas dos ombudsmen de $O$ Povo e da Folha, conforme mostra o Gráfico 1 a seguir. Entre os apontamentos críticos estão as posições ideológicas de $O$ Povo em relação à cobertura do julgamento do ex-presidente Lula e da greve dos caminhoneiros, ou na defesa da prática profissional, como o caso de violência contra um jornalista do jornal. As manifestações dos leitores não representam o principal componente da crítica nordestina, conforme identificado nos textos de Paulo Verlaine, que preferia dar exemplos práticos dos leitores, por considerar que as críticas dos demais jornais não se atentava a fatos concretos (BORCEZI, 2008). 
Gráfico 1 - Análise dos jornais O Povo e Folha de S. Paulo.

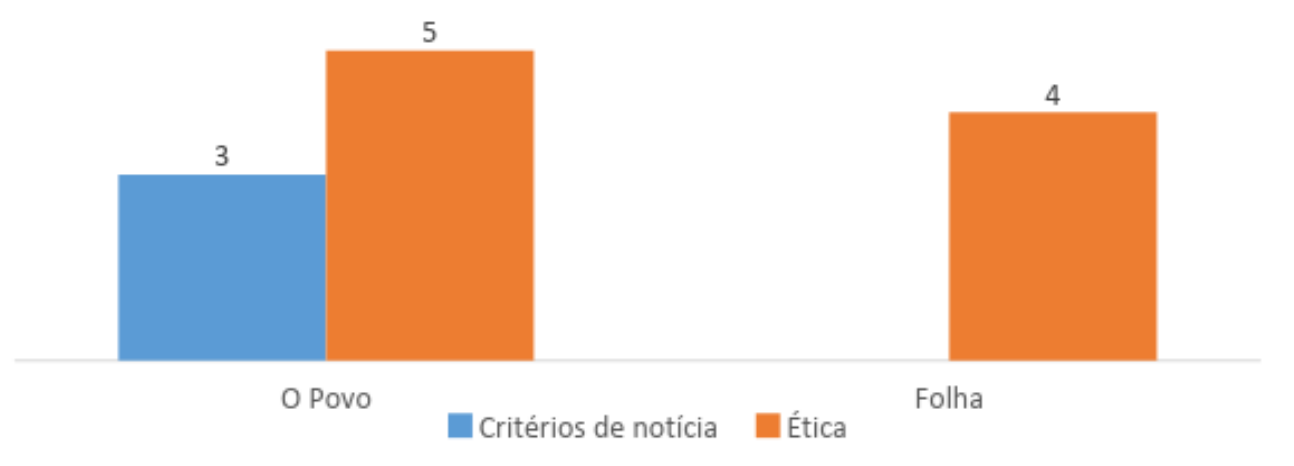

Fonte: Elaboração dos autores.

Nos textos da ombudsman Daniela Nogueira, a interlocução do público não é uma constante, pois há críticas em que as reclamações aparecem numa perspectiva genérica, como pode ser observado no texto "Qual dor sai no jornal?", do dia três de maio de 2018, sobre o destaque na primeira página do jornal das mortes ocorridas em Fortaleza: "O fato tem incomodado leitores, que se queixaram por que motivo uns crimes recebem tanto destaque no O POVO, enquanto outras mortes são noticiadas em espaço menor”. Já a crítica “A opinião e a matéria”, do dia seis de maio de 2018, diz: "Não são poucas as críticas que a mim chegam, todos os dias, pelos diversos meios, sob a acusação de que o jornal está a favorecer certo partido político [...]”" (NOGUEIRA, 2018, não paginado).

O modo com que as reclamações do público estão apresentadas na Coluna reafirma ainda mais o posicionamento discursivo do ombudsman, o qual parece não estar influenciado pelos novos dispositivos digitais, quando se tem como parâmetros de crítica às manifestações advindas do Conselho de Leitor do jornal, conforme exemplificado a seguir.

Dois membros do Conselho de Leitores perceberam uma "defesa de Lula" por parte do jornal. "A maioria dos textos produzidos (pelos jornalistas e por especialistas convidados) fez (consciente ou inconscientemente) uma defesa da tese do Lula, ou seja, perseguição política. Concordo com essa tese, mas acredito que o jornal poderia fazer um esforço maior para diversificar suas linhas de análise. Se continuar assim, poderá ser identificado como publicação da esquerda. Façam um embate! Explorem as polarizações”, analisou o sociólogo Cleyton Monte, pesquisador da área de política (NOGUEIRA, 2018, não paginado).

Um dos objetivos do Conselho é avaliar a qualidade informativa no sentido de subsidiar decisões internas do jornal. Segundo Braga (2006), essa instituição geralmente 
é formada por participantes que possuem leituras habituais do periódico e, assim, estão aptos para avaliar o produto. Talvez, hoje, o principal dilema enfrentado pelos ombudsmen seja identificar os tradicionais leitores do jornal nas redes digitais e atribuir credibilidade a esse lugar de fala, em que muitos interagem e nem mesmo obtêm acesso à notícia pelo jornal.

Gráfico 2 - Análise da participação dos leitores e profissionais da redação entre 2008 e 2018.

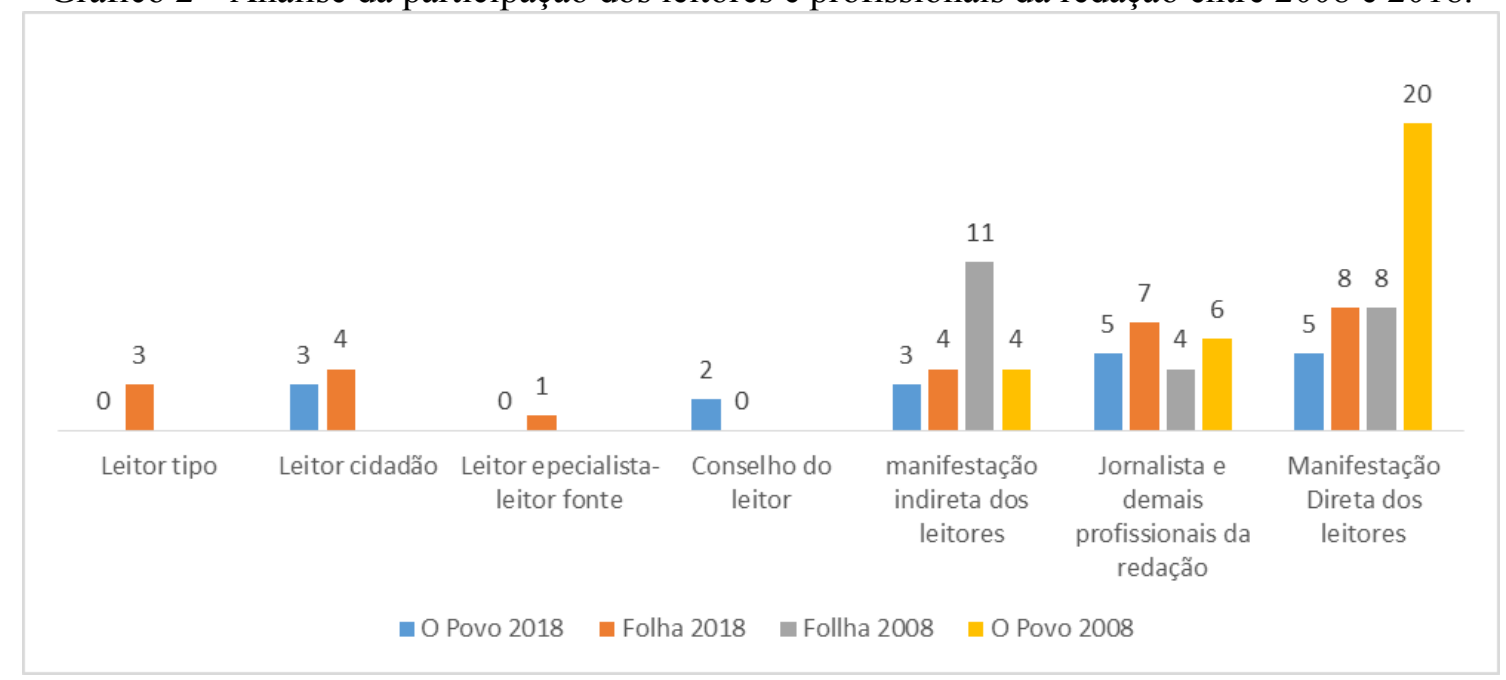

Fonte: Elaboração dos autores

Os níveis de participação dos leitores e da redação nas colunas dos ombudsmen, conforme mostra o Gráfico 2, representam significativas mudanças durante o período de análise, pois, na Folha, há maior interlocução com os profissionais de mídia, bem como houve redução das manifestações indiretas dos leitores. Em O Povo, o discurso do ombudsman está mais ponderado entre as suas críticas para o jornal e as reclamações do público. Neste sentido, pode-se dizer que, com os efeitos da midiatização, o ombudsman tende a buscar novos parâmetros de criticidade ou manter-se na sua posição tradicional de mediador.

A ombudsman Daniela Nogueira mostra-se cautelosa sobre os novos paradigmas que têm norteado a prática jornalística, como foi identificado no texto "O POVO na internet", do dia 20 de maio de 2018, quando alerta o jornal sobre a velocidade na publicação de informação e o furo de reportagem no meio on-line, o que pode levar ao erro de informação ou a uma publicação incompleta, além de chamar a atenção para o compromisso com o interesse público.

Nas mídias sociais do O POVO, as postagens de conteúdo lúdico são extremamente recorrentes. Não devem ser banidas, mas deve haver mais equilíbrio no que estamos publicando. É preciso nos lembrarmos, a todo momento, o que é "interesse público" e o que é "interesse do público", duas 
expressões-chave que os jornalistas aprendem desde cedo e que nunca deveriam esquecer - ou das quais deveriam sempre se lembrar (NOGUEIRA, 2018, não paginado).

Dito de outro modo, a emergência desses espaços de circulação gera complexidade na produção jornalística e as estratégias de leitura da mídia pela ombudsman parece delimitar as fronteiras entre produtor e receptor ao autorreferenciar o processo produtivo do jornal. "É nesta complexa enunciação que o jornal faz emergir sua identidade, e as características do seu modo de falar, bem como possibilidades do leitor estabelecer processos de reconhecimento da sua presença" (FAUSTO NETO, 2007, p. 4).

\section{Agenda da mídia ou agenda do público (tematização)?}

A proposta conceitual da Teoria da Agenda desenvolvida por McCombs (2009) ajuda a problematiza a inter-relação entre os interesses de participação do público e a consequente referenciarão pela crítica. Uma das premissas da hipótese da agenda setting em tempos de midiatização é o contrafluxo da agenda, ou seja, a sociedade pauta a mídia por meio dos dispositivos digitais (MACCOMBS, 2009). Lopes (2013) entende que as redes sociais transferem sua saliência para a agenda midiática e criam, assim, novos fluxos de agendamento, bem como tencionam a concepção clássica da Teoria da Agenda, de que a mídia determina quais os assuntos merecem a atenção do público.

Tal perspectiva nos faz refletir se a mesma lógica se aplica às colunas dos ombudsmen, pois a visibilidade de determinados temas é justificada pela aclamação do público. No entanto, uma análise comparativa entre os jornais Folha de S. Paulo e $O$ Povo permite observar certa homogeneidade de temas nas críticas dos ombudsmen, seja os assuntos primários, que ocupam o título da, ou assuntos secundários discutidos no decorrer do texto, conforme dados compilados no Gráfico 3. 
Gráfico 3 - Temas das colunas dos ombudsmen nos jornais O Povo e Folha de S. Paulo.

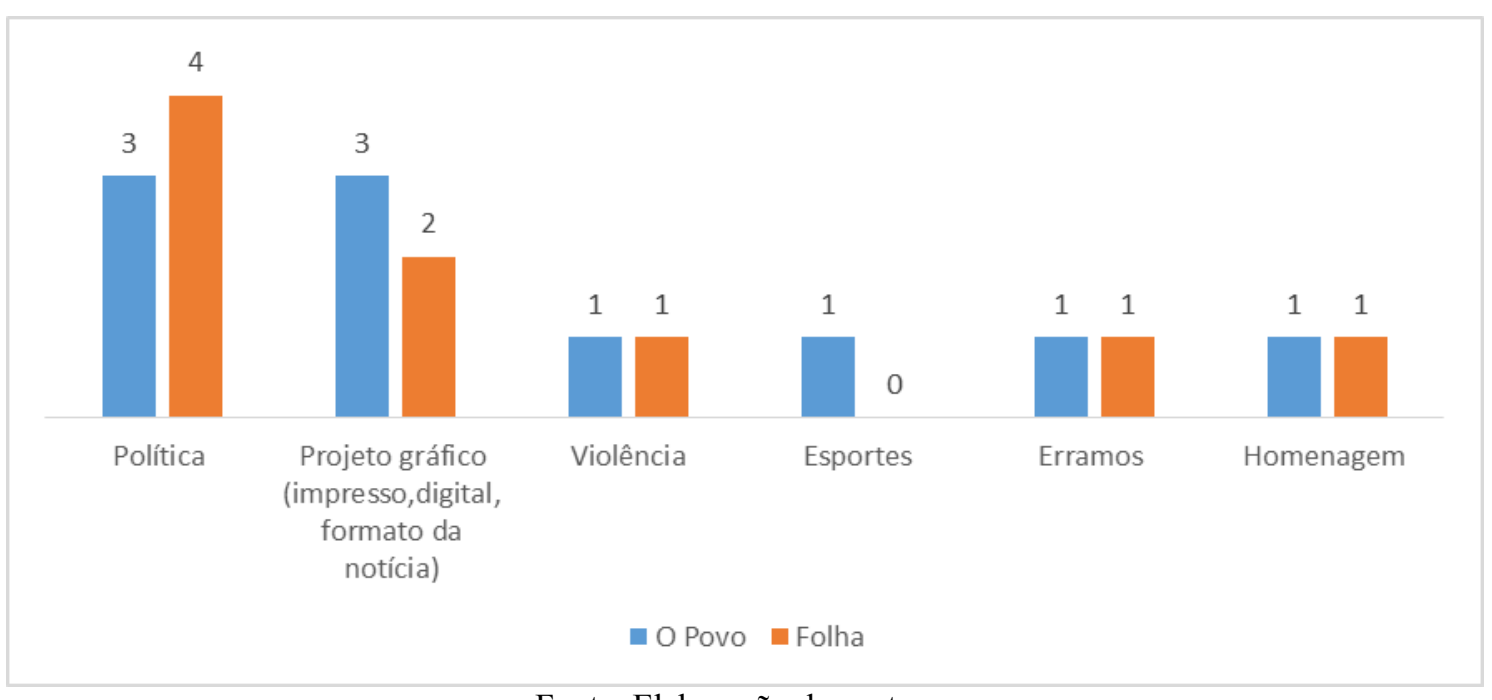

Fonte: Elaboração dos autores

Desse modo, supõe-se um interagendamento midiático nas colunas dos ombudsmen, que consiste em um agendamento dentro da própria agenda midiática e se processa quando os jornalistas observam aquilo que é publicado pelos competidores diretos (MCCOMBS, 2009).

Apesar dessa perspectiva não ter sido um dos principais objetivos do trabalho de conclusão de curso sobre as críticas do ombudsman em 2008, ainda assim foi possível identificar tendência dos mesmos temas nas colunas, como as intrigas políticas da época.

\section{Considerações finais}

$\mathrm{Na}$ proposta de atualizar os conceitos discutidos no trabalho de conclusão de curso sob a perspectiva de uma sociedade midiatizada, novos parâmetros de crítica e posicionamento discursivo dos ombudsmen foram observados.

No primeiro momento, pressupunha que o dinamismo dos espaços digitais estabeleceria uma nova ordem discursiva em todas as colunas dos ombudsmen que se conservaram desde 2008. Tal perspectiva de reinvenção pode ser constatada nas críticas jornalística da Folha, que tem como parâmetro de análise do jornal as manifestações do público nas redes sociais. Diferente das cartas dos leitores, essa nova seara, que comporta um público difuso, provoca tensões de outros atores sociais que escapam até mesmo do controle editorial, como o furo de reportagem de um experiente jornalista ao apontar um erro de informação da Folha nas redes sociais. Portanto, a interdiscursividade do ombudsman tornou-se mais dinâmica, aberta aos feedbacks dos 
jornalistas, às reclamações diretas dos leitores e ao posicionamento de um ombudsman que se autorreferência representante do leitor.

De outro modo, o discurso do ombudsman de $\mathrm{O}$ Povo ainda preserva características de um ouvidor tradicional, que se atêm às críticas endereçadas aos espaços próprios de crítica do jornal, como o Conselho de Leitor. Portanto, a interdiscursividade não está atravessada pelas lógicas dos novos processos interacionais, ao menos não é um critério referenciado pelo ombudsman.

Neste contexto de midiatização cabem duas reflexões sobre o posicionamento dos ombudsmen nos jornais: Até que ponto torna-se necessário levar em consideração as manifestações dos leitores nas mídias digitais, considerando que é um público difuso e nem sempre é o leitor do jornal; e em que medida essas mesmas mídias podem ser ignoradas como parâmetros de criticidade, se também são um canal de demandas e termômetro de (in)satisfação do público. Neste sentido, acredita-se que essas questões são um dos principais aspectos a serem refletidos pelos profissionais a ponto de tornálos objetivados no Manual de redação digital dos jornais.

Embora a expansão da midiatização tenha afetado a produção jornalística, esse fenômeno reforça ainda mais a necessidade dos espaços dos ombudsmen, como controller de qualidade de informação, algo que ainda não se consolidou no Brasil.

\section{Referências}

BORCEZI, Daniela. Os vigilantes também são vigiados: o papel do ombudsman nos jornais brasileiros. 2008. Trabalho de Conclusão de Curso (Jornalismo) Universidade Estadual de Ponta Grossa, Ponta Grossa, 2008.

BRAGA, José Luiz. A sociedade enfrenta sua mídia. São Paulo: Paulus, 2006.

BRONOSKY, Marcelo Engel. Manuais de redação e jornalistas: estratégias de apropriação. Ponta Grossa: UEPG, 2010.

BRONOSKY, Marcelo Engel; SANTOS, Luciane Justus dos. Jornalismo independente: ombudsman e espaço para interação com leitores. In: ENCONTRO NACIONAL DE PESQUISADORES EM JORNALISMO, 16., São Paulo, 2018. Anais [...]. São Paulo: SBPJOR, 2018. Disponível em: http://sbpjor.org.br/congresso/index.php/sbpjor/sbpjor2018/paper/viewFile/1699/711. Acesso em: 05 abr. 2019.

CARVALHO, Carlos Alberto de; LAGE, Leandro Rodrigues. Midiatização e reflexividade das mediações jornalísticas. In: MATTOS, Maria Ângela; JANOTTI JUNIOR, Jeder; JACKS, Nilda (org.). Mediação e midiatização. Salvador: EDUFBA; Brasília: COMPÓS, 2012. p. 245-269. Disponível em: http://books.scielo.org/id/k64dr/pdf/mattos-9788523212056.pdf. Acesso em: 30 jun. 
2018.

COSTA, Paula Cesarino. Distanciamento histórico. Folha de S. Paulo, 08 maio 2018. Disponível em [para assinantes]: https://www1.folha.uol.com.br/colunas/paulacesarino-costa-ombudsman/2018/04/distanciamento-historico.shtml. Acesso em: 30 jun. 2018.

COSTA, Paula Cesarino. Esperando João na rua errada. Folha de S. Paulo, 06 maio 2018. Disponível em [para assinantes]: https://www1.folha.uol.com.br/colunas/paulacesarino-costa-ombudsman/2018/05/esperando-joao-na-rua-errada.shtml. Acesso em: 30 jun. 2018.

COSTA, Paula Cesarino. Por um fio. Folha de S. Paulo, 22 abr. 2018. Disponível em [para assinantes]: https://www1.folha.uol.com.br/colunas/paula-cesarino-costaombudsman/2018/04/por-um-fio.shtml. Acesso em: 30 jun. 2018.

FAUSTO NETO, Antonio. A circulação além das bordas. In: Mediatizacion, sociedad y sentido: diálogos entre Brasil y Argentina. Rosario: Universidad Nacional de Rosario, ago. 2010, p. 2-17. Disponível em: http://www.fcpolit.unr.edu.ar/wpcontent/uploads/Mediatizaci\%C3\%B3n-sociedad-y-sentido.pdf. Acesso em: 03 jul. 2018 .

FAUSTO NETO, Antonio. Contratos de leitura: entre regulações e deslocamentos. Revista Diálogos Possíveis, Salvador, ano 6, n. 2, p. 7-27, jul./dez. 2007. Disponível em:

http://revistas.faculdadesocial.edu.br/index.php/dialogospossiveis/article/view/168/125. Acesso: 05 jul. 2018.

FAUSTO NETO, Antonio. Ombudsman: a interrupção de uma fala transversal. Revista Intexto, Porto Alegre, v. 2, n. 19, p. 1-15, jul./dez. 2008. Disponível em: http://seer.ufrgs.br/index.php/intexto/article/view/8009. Acesso em: 01 jul. 2018.

FRANZONI, Sabrina. O Blog do Ombudsman: interação e auto-referencia no ciberespaço. CONGRESSO BRASILEIRO DE CIÊNCIAS DA COMUNICAÇÃO, 32 ., Curitiba, $2009 . \quad$ Disponível em: http://www.intercom.org.br/papers/nacionais/2009/resumos/R4-2407-1.pdf. Acesso em: 30 jun. 2018.

GADINI, Sérgio Luiz. Breve história da crítica de mídia no Paraná: experiências de ombudsman em produtos jornalísticos nos campos gerais. Revista Conexão Comunicação e Cultura, Caxias do Sul, v. 16, n. 32, p. 1870198, jul./dez. 2017. Disponível em: http://www.ucs.br/etc/revistas/index.php/conexao/article/view/5072/3285. Acesso em: 05 jul. 2018.

LOPES, Gustavo Chaves. As redes sociais e os novos fluxos de agendamento: uma análise da cobertura da Al Jazeera sobre a Primavera Árabe. Palabra Clave [online], v. 16, n. 3, p. 789-811, dic. 2013. Disponível em: http://www.scielo.org.co/scielo.php?script=sci_abstract\&pid=S0122$82852013000300006 \& \operatorname{lng}=\mathrm{e} \& \mathrm{nrm}=$ iso. Acesso em: 16 nov. 2017. 
MADEIRA, Bruna; CARDOSO, Lenize Villaça. A crítica de mídia e o papel do ombudsman na era digital: transformações e adaptações. In: CONGRESSO BRASILEIRO DE CIÊNCIAS DA COMUNICAÇÃO, 39., São Paulo, 2016. Anais [...] São Paulo: Intercom, 2016. Disponível em: http://portalintercom.org.br/anais/nacional2016/resumos/R11-1736-1.pdf. Acesso em: 05 abr. 2019.

MESQUITA, Mario. Um mediador português na imprensa diária. In: BERTRAND, Claude Jean. O arsenal da democracia: sistemas de responsabilização da mídia. Bauru: EDUSC, 2002. p. 231-239.

McCOMBS, Maxwell. A teoria da agenda: a mídia e a opinião pública. Petrópolis, RJ: Vozes, 2009.

NOGUEIRA, Daniela. Equilíbrio, notícia e espetáculo. O Povo, Fortaleza, 08 abr. 2018. Disponível em: https://www.opovo.com.br/jornal/colunas/ombudsman/2018/04/equilibrio-noticia-eespetaculo.html. Acesso em: 30 jun. 2018.

NOGUEIRA, Daniela. O Povo na internet. O Povo, 20 maio 2018. Disponível em: https://www.opovo.com.br/jornal/colunas/ombudsman/2018/05/o-povo-nainternet.html. Acesso em: 30 jun. 2018.

NOGUEIRA, Daniela. Qual dor sai no jornal? O Povo, Fortaleza, 13 maio 2018. Disponível em: https://www.opovo.com.br/jornal/colunas/ombudsman/2018/05/qualdor-sai-no-jornal.html. Acesso em: 30 jun. 2018.

PRUDENCIO, Kelly; ROSAS, Juliana de Amorim. O ombudsman como estratégia. CONGRESSO DE CIÊNCIAS DA COMUNICAÇÃO NA REGIÃO SUL, 15., Palhoça, SC, 2014. Anais [...]. São Paulo: Intercom, 2014. Disponível em: http://portalintercom.org.br/anais/sul2014/resumos/R40-0676-1.pdf. Acesso em: 02 jul. 2018.

Submetido em: 31.10.2019

Aprovado em: 20.03.2020 